\title{
空調設備の保全の記録方法に関 STUDY ON METHOD OF RECORDING する研究 AIR CONDITIONING SYSTEM MAINTENANCE
}

\section{高草木 明 一 $* 1$}

キーワード :

空㽢設僙, 保全, 管理, 保全町録

Keywords :

Air-conditioning system, Maintenance, Manegement, Maintenance record

\section{Akira TAKAKUSAGI $-* 1$}

A method has been developed to effectively and concisely record maintenance performed on air conditioning systems. Here, to represent the nature of faults and to enable maintenance record to be selected, classifications are established for types and severity of loss, mode and mechanism, and information for predicting faults. Maintenance mode is classified as a combination of maintenance policy and maintenance measure. The basis for determining maintenance expenditure. which must also be recorded, is classified as well. Several examples of maintenance records using the above classifications are presented.

\section{はじめに}

空調設備はその本来の機能を発揮するように正常運転が維持され、 故障、欠陥などが生じた場合、速やかに回復されなければならない。 これを達成する任務は「保全」注1に課せられている。保全は空調設 備に直接的に手を加える行為であり、保全行為の品質のためには、 故障物理などに基つく固有技術が基瞥となる。

空調設備は建築の重要な機能を担い、ライフサイクルコストが大 きく企業財務に少なからず影算を及ほし、社会的問題（環境問題、 資源枯渴問題）に関わろエネルギー使用量が大きい。また、空謂が 担う室内㻴境の質は、企業の生産性に関わる要素である。従って、 これを所有する企業は重要な資産と捉え経営的立場から相応の関心 を持つ。よって、空調設備は「管理」の対象となる。管理の任務は、 空調設備のライフサイクルにわたる効果的な活用をはかるための計 画・統制・調整である注2 。この任務は、決定された経営意志に従っ て、経営計画の運営・維持を目的とするものでなければなければな らない ${ }^{\text {主3 }}$

「管理」の対象となる設備であるところの空調設備の「保全」は、 場当たり的な保全行動が許されない。保全は「管理」により与えら れる方針に従って遂行されなければならない。保全そのものの品質 は保全の固有技術に掛かるものであるが、保全を実施する時期や投 資規模の妥当性は、建物所有企業に対して「管理」が車任を負う。 保全に与える方針の立案方法は、管理工学の技術として位置つけ られる。著者はこれまでに建筑設備分野において、状態基準予防保 全に実施方針として最適な点検周期を与える方法の研究 ${ }^{3)}$ 【オー バーホールなどの物理的劣化を回復するための保全の中長期的実施
計画を立てる方法の研究 ${ }^{5)}$ 、設備機器の更新の判断方針の研究 ${ }^{6)}$ 、 更に大規模な保全行為であるリノベーションの企画・計画のための 投資の方針を与える研究"なな゙を進めてきた。このような管理技術 を実際に適用するためには基整的なデータの不足が否めない。これ は主に個々の現場での保全の記録の不備に起因する。管理技術の立 場から保全の記録方法について方針を与えることが必要である。こ の記録の蓄積は、管理が保全に与える諸方針の品質向上に寄与する のみならす、保全とともに管理の対象となる「設計」における方針 に、有益な基碳デー夕を提供するものともなる。更に、脰富な蓄積 が実現すれば、保全の実態を体系的に整理して全体像を把㩧するた めの基礎的データとなるものと考えられる。

空調設備の保全は、不具合に対する対処と捉えることができる。 保全は管理の方針に従って為される。従って、保全の記録は、不具 合の記述と対処方法、及び従った管理上の方針の記述とから構成さ れるべものである。本研究は、空調設備に生じる不具合、保全モ 一ドおよび賈用支出判断根莇を網羅的に分類整理して、個々の保全 現場での不具合と保全について、当てはまる項目の選択により保全 を効率的に、簡挲に、かつ蓄㵒された記録を分析しやすく記録とし て記述する方法を開発することを目的とする。

\section{1 . 不具合の記述}

\section{1-1 不㚳用の内容と程度}

個々の不具合に対し、それによって建物所有企業や居住者が被る 不効用の内容と程度を分類整理する。先ず、現に不効用を生してい る場合と、先々の不効用発生につながることが予見される場合とを 
表 1 不効用発生時期からの不具合の分類

現時点で不効用を生じている。

先々の不効用発生が予見される。（現時点で 保全が必要と判断される場合に限る）

表 2 不効用の内容からの不具合の分類

\begin{tabular}{|cc|}
\hline \multicolumn{2}{|c|}{ 不効用の内容の区分 } \\
\hline 経済性 & 健康性 \\
块適性 & 安全性 \\
利便性 & 社会性 \\
\hline
\end{tabular}

表 3 不効用の程度からの不具合の分類

\begin{tabular}{|c|c|}
\hline 尺度 & 定量的記録項目 \\
\hline 信頼性の低さ & $\begin{array}{l}\text { 不具合の発生の日時 } \\
\text { 不具合の回復の日時 }\end{array}$ \\
\hline 損失の程度 & $\begin{array}{l}\text { 損失金額、損失の金額への換算 } \\
\text { エネルギー消䚉量過剩分その他理境 } \\
\text { 負荷過剩分 } \\
\text { その他、状況記述 }\end{array}$ \\
\hline 対処のコスト & 設備修復・更改等に要する金額 \\
\hline
\end{tabular}

表 1に示すように区別する。後者は、現時点で先々のために保全を 行うことが妥当と認められた場合にのみ不具合として認識するもの とする。この場合の不効用の内容と程度は予測となる。

不効用の内容は不具合の分類観点の一つとなる。不効用の内容の 区分は、経済性に関わるもの、快適性、利便性に関わるもの、居住 者の健康、安全に関わるもの、地域・地球環境への影望として社会 性の観点から評価するべきすのである。これを表 2 に示す。

不効用の程度 (深刻度) の定量評価も不具合の分類観点の一つ之 なる。不効用の程度は、設備機能の信頼性・保全性亡不具合により 生じた損失（金額、環境負荷等）の程度、及び対処に要する金額に よって定量化される。表 3 に不効用の程度からの不具合の分類とし て不効用の尺度とそれに関して定量的に記録すべき項目を示す。不 具合の発生と回復の日時の記録は、応急的処置を要する不具合に限 り、不具合の発生頻度と修復に要する時間とを求めるためのもので あり、信頼性・保全性の低さの程度が評価される。

\section{1-2 不具合のメカニスムとモード}

不具合は、原因または症状を表す現象として「不具合のモード」 と、不具合の発生の背固として物理的変化の現象または人的・社会 的変化の現象を表現する「不具合のメカニズム」とによって表現で きる。モードは実際に生じた不具合において観測可能なものである が、メカニズムは不明ということが有り得る。故障の伝搬などによ り一つのモードに対してメカニズムは複数となることもある。

不具合のモードの観測は目視できない場合も多く、必ずしも容易 なものではない。保全に先立つ「診断」では、不具合のモードをで きるだけ定量的に観測する。更に可能であればメカニズムの解明を 行う。「不具合のモード」と「不具合のメカニズム」によって不具 合に対処する保全行為の固有技街的原理をおのすと抽出することが 可能となり、保全方法が導かれる。

空調設備に発生する不具合のメカニズムの分類を表 4 に、不具合 のモードの分類を表 5 に示す。物理的不具合のモードには「障害の 種別」を含める。表 4 、表 5 の不具合のモードやメカニズムの分類
表 4 不具合発生のメカニズム

\begin{tabular}{|c|c|}
\hline 動作ストレス & $\begin{array}{l}\text { 機械的作用による損耗（摩耗、Iロ-ジョシ） } \\
\text { 機械的作用による疲労 } \\
\text { 振動によるゆるみ }\end{array}$ \\
\hline 嘖境ストレス & 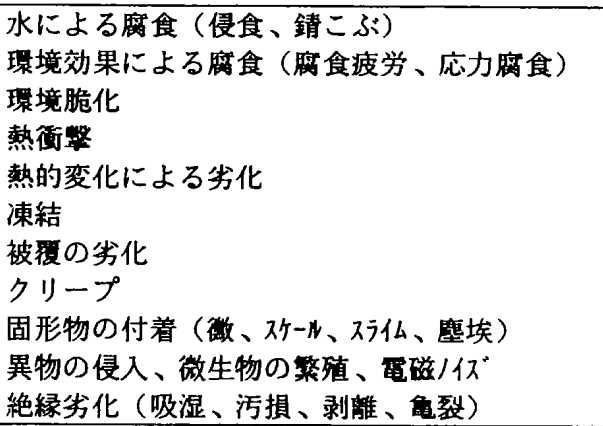 \\
\hline \multicolumn{2}{|c|}{ 他の部品、機器の不具合からの伝搬 } \\
\hline \multicolumn{2}{|c|}{ 人為的・社会的メカニズム } \\
\hline 人為的ミス & $\begin{array}{l}\text { 運用面での人為ミス（唄操作、俱使用、保全 } \\
\text { 買の不足、連絡ミス） } \\
\text { 建設時の人為ミス（設計、施工、選定のミス） }\end{array}$ \\
\hline 社会的変化 & $\begin{array}{l}\text { インフラ異常（供給異常、供給停止） } \\
\text { 陳腐化1（要求性能の水準の上昇） } \\
\text { 陳腐化2（技術進歩による相対的性能低下） } \\
\text { 法規不適合（遡及耗務、既存不適格） } \\
\text { 地球・地域璵境問題（規制、自主対応） }\end{array}$ \\
\hline
\end{tabular}

表 5 不具合のモード

\begin{tabular}{|c|c|}
\hline \multicolumn{2}{|l|}{ 物理的不具合 } \\
\hline \multicolumn{2}{|l|}{ 噇害種別 } \\
\hline \multicolumn{2}{|c|}{$\begin{array}{l}\text { 機能低下（応急的対応必要）、機能低下（応急的対応不要） } \\
\text { 機能停止 } \\
\text { 劣化促進要因の拡大 }\end{array}$} \\
\hline 椇傷 & $\begin{array}{l}\text { 割れ、攵け、裂、脱落、切損、破損、剥離、 } \\
\text { 剥落、減耗、減肉 }\end{array}$ \\
\hline 動きの異常 & $\begin{array}{l}\text { 停止、嘈み合い不良、ずれ、ゆるみ、詰まり、 } \\
\text { バランス不良、ミ仍ライメン、基礎不良、流体振動 }\end{array}$ \\
\hline 流れの異常 & $\begin{array}{l}\text { 停止、漏れ、微小漏れ、詰まり、粘性不良、 } \\
\text { 循環不良、排出 }\end{array}$ \\
\hline 水㯳水位異常 & 高水位、低水位、溢れ出 \\
\hline 相変化の異常 & 凝結、凝固、蒸発、融解 \\
\hline 劣化促進 & 被覆の損稘、鹰食 \\
\hline 変形 & 曲がり、ゆがみ \\
\hline 変質 & 弾性低下、変色、僈色 \\
\hline 絶縁不良等 & $\begin{array}{l}\text { 漏れ電流增大、トランキシグ、部分放简発生、部分 } \\
\text { 放電侵食、電磁/イズによる镇動作 }\end{array}$ \\
\hline 熱伝達の阻害 & 污れ \\
\hline 環境阻害 & 騷音、掁動、電磁/沿放出 \\
\hline 衛生阻害 & 水質不良、空気質不良 \\
\hline \multicolumn{2}{|c|}{\begin{tabular}{l|l} 
全体的劣化 & \\
\end{tabular}} \\
\hline \multicolumn{2}{|c|}{ 人為的・社会的不具合 } \\
\hline 姓能不良 & 電気・ガス・水の過剩消費、設計・施工不良 \\
\hline 室内㻴境不良 & 温熱環境、空気質 \\
\hline 保全作業阻害 & 作業場所へのアクセス不良、安全性不良 \\
\hline インフラ異常 & 電力、上下水、ガス、地域熱供給 \\
\hline 陳腐化 & 経済性、省工神ギー性、快適性、利便性、安全性 \\
\hline 法規不適合等 & 官公庁の指摘、安全性不安、耐票性不良 \\
\hline
\end{tabular}

において、選択肢として網羅的であることが重要である。これらの 表は著者による文献 5 ）８）の調查におけるデー夕の分析、及び文 献 9 ） 10）等から作成したものであるが、これで建築設備に生じ るあらゆる不具合に対して万全であるという保証はない。しかし、 この記録方法が保全記録の実務に適用され、実務を通じて新たなモ 
ードやメカニズムが追加されることによって充実したものとなって ゆくと考えられる。

\section{1-3 不具合の予鳃情報}

物理的劣化による故障に対する保全で、予知保全方針を採る場合 には、点検によって故障の前兆を検出する。故障の前兆とは現時点 で空調機能に支障はないか、やがて発生する故障の予测情報である。 時間基準保全方針が採られている場合には、予め不具合の発生時期 を予測して保全周期が決められている。よって、規定の保全周期が 不具合の予測情報に他ならない。

人的・社会的な変化や異常の現象を背景とした不具合については、 建物所有者や居住者が不具合を認知する以前に専門家である保全技 術者によって不具合の状況が把暒され、あるいは不具合の発生が予 测され、予防的な保全を行うことが提案されることがある。これは、 居住者のクレームなどとともに保全実施の動機となる。これは故障 の予知保全における兆候検出に相当するといえよう。

予防的保全を動機つける不具合の予測情報は、保全の位置つけに 必要な要素であり、保全記録に含めるべき事項として表 6 に示す。

表 6 不具合の予測情報（事後保全方針の場合は該当せず）

\begin{tabular}{|c|c|c|}
\hline 応急的処置を & 予知保全方針の場合 & 時間基㴗保全方針の場合 \\
\hline $\begin{array}{l}\text { 要する不具合 } \\
\text { に対する予防 } \\
\text { 保全のための } \\
\text { 予測情報 }\end{array}$ & $\begin{array}{l}\text { 情報(故障前兆) 無 } L \\
\text { 異臭 } \\
\text { 異音 } \\
\text { 異常振動 } \\
\text { 過熱 } \\
\text { 压力異常 } \\
\text { 流量異常 } \\
\text { 電流值異常 } \\
\text { 電压異常 } \\
\text { 絶緑抵抗値異常 } \\
\text { 見えがかり }\end{array}$ & $\begin{array}{l}\text { 情報無し（規定時間前の } \\
\text { 発生） } \\
\text { 規定の保全周期 }\end{array}$ \\
\hline $\begin{array}{l}\text { 応急的処置を } \\
\text { 要しない不具 } \\
\text { 合に対する予 } \\
\text { 防的保全のた } \\
\text { め予測情報 }\end{array}$ & $\begin{array}{l}\text { エネルギー消費量の } \\
\text { 室内㻴境、衛生の水 } \\
\text { 污れの增加 } \\
\text { 馶音・振動の增加 } \\
\text { 見えがかり } \\
\text { 全体的劣化進行 } \\
\text { 最新技術との格差 } \\
\text { 最新設備性能との格 } \\
\text { 法規改正に伴う不適 } \\
\text { 居住者のクレーム增 } \\
\text { 建物所有者の不满 }\end{array}$ & $\begin{array}{l}\text { 曾加 } \\
\text { 䇺低下 }\end{array}$ \\
\hline
\end{tabular}

\section{1ー4 記録の䔄樍による不具合の糊羅}

空調設備に発生する不具合を網羅的に捉えることによって、不具 合に対する保全モードは自ずと網羅される。よって保全の全体像を 捉えるという目的に対しては、不具合を網羅する方法の検砷が重要 である。物理的な不具合である故障のメカニズムを演繹的に網羅し 得るという前提に立ち、安全性・信頼性の予测的解析を行う手法と して、F T A (Fault Tree Analysis) દFME A (Failure Hode and Effects Analysis) ${ }^{11}$ がある。保全記録の蓄皘の意義をこれら と比較しておこう。

F T A は特定の事象に関して予測的な信頼性解析を行う手段であ り、対象事象に関しては故障メカニズムを網羅的に記述することが
できるが、空調設備に生じる不具合は多栐で、その一つ一つを F T 図で記述することは困難である。また、最下段に位置づけられる各 イベントの生起䧴率について決定的にデータが不足している。F T 図はその作成方法が確立していないという問題点があり、同し事象 についても作成者によって違ったものとなってしまう”。従って、 F T 図の作成のみに留まっている限り、いくつかの故障モードにつ いての定性的な検討のまとめ程度の意味しかない。

一方、FME Aは、ある要素の故障から出発して、その故障が周 囲にどのような影㘹を与えるかをたどる、F T Aと逆の探索を行う 方法である。故障モードに着目して、その影整を解析することが目 的である。F ME Aは構成要素の限られた特定のシステムの開発等 において有効であるが、空調システム全体への適用は困難である。 F T A 、F M E Aとも、個人あるいは組織単位で短期的に行うこと を想定した演繹的な方法である点が、適用面での負担が大きい原因 であると考えられる。

空調設備は、保全員や建物管理者によって日々の保全記録が取ら れていることが多い。一つ一つの不具合についてのモードとメカニ ズムの記録は、F T A るいはF ME Aの一つの経路を示したこと になる。多数の建物において記録方法を統一して、このような記録 を集積して分析すれば、帰納的に空調設備に発生する不具合の全貌 を捉えることができると考えられ、それは不具合の網羅という目的 のためには、F T A P F M A A りも現実的であると考えられる。

\section{2 保全の記述}

保全記録におけろ保全についての記述は、保全モードを分類整理 しておいて該当するものを選択する方法とする。保全モードは、保 全実施方針と、保全処置それぞれの分類項目の組み合わせにより、 分類する。保全実施方針は、管理側から見た保全の分類観点であり、 保全処置は、不具合の内容から導かれる。

保全対象は、部品レベル、機器レベル、システムレベルの 3 階首 を考える。機器レベルには、配管系、ダクト系を含めるものとする。

\section{2-1 保全実施方針の分類}

個々の保全の実施方針は次の 3 項目を分類要素とする。

(1) 保全処置の種別判断とそれを個々に実施するか、総合的に実施 するかの区分。

(2) 実施時期について、応急的あるいは計画的に行うかの区分。こ こで、計画的とは、応急的とする必要がなく、保全員がある程 度の期間の幅のうちで実施時期を決めることができるというこ とを意味する。

（3）保全方策として、予防保全（時間基準保全または状態基準保全） とするか、事後保全とするかの区分。

これら(1)(2)(3)の組み合わせを空調設備保全の管理上の分類のため の分類観点とする。

\section{2-2 保全処軍の分類}

保全は設備に直接的に手を加える行為であり、除去、付加、移動、 およびこれらの組み合わせ、によってなされる。

除去と付加が部品や機器等に対してなされるのが「取換え」であ る。取り替えには「単純反復取り替え」と「改良取り替え」とがあ 
る。システムの除去と付加は、「システム更新」である。

除去のみの保全行為は、「洗浄・清掃」とする。「調整」は、設 定変更、修正の手段として、除去か付加かの選択（例えば溶液の浱 度調整など）、ハンドル、レバーなどの移動（流量調整など）によ って行われる。「補強・補修」は部品レベルにおける付加のみの保 全行為、移動による変形の回復、機器等の部分に対する除去と付加 の混在した保全行為が含まれるる)。

以上より、保全処置の分類は、部品レベルの保全では、「取換え 修理」、「洗浄・清掃」、「調整」、「補強・補修」となる。これ らを総合的に実施する場合は、「オーバーホール」であり、これも 保全処置の分類に加える。機器レベルの保全では「機器の取換え」、 システムレベルの保全では「システム更新」となる。

\section{2-3 保全モードの分類}

2ー1に示した 3 項目の保全実施方針の分類と、2-2に示した 保全処置の分類の組み合わせにより、部品レベル、機器レベル、シ ステムレベルそれぞれの保全モードを整理する。全ての組み合わせ の中から、実際に有り得る組み合わせを抽出して保全モードとする。 （1）部品レベルの保全モード

部品レベルの保全には応急的に行う保全と計画的に行う保全とに 大別される。表 7 に部品レベルの保全モードの分類を示す。

a . 応急的に行う保全の保全モード

応急的に行う保全は空調機能の信頼性にかかわるもので、機能の 停止、あるいは予め定められた使用時間・運転時間が経過した場合、 または判定基準以下に機能が低下した場合の処置である。このよう な故障は偶発的に発生すると考えられ、これに対する予防保全方策 は「洔間基準保全」、または「状態基準保全（予知保全）」である。 応急処置が必要な故障の事後保全は「腎急保全」である。

応急的に行う保全は、信頼性だけを問題とすることとすれば、保 全処置の種別は管理上重要ではないので、保全処置種別による区分 は行わないこととする。

b. 計画的に行う保全の保全モード

徐々に低下してくる機能の回復や少化の抑制を目的とする保全は 応急的処置とする必要はなく、実施時期を保全現場の都合などによ り計画的に定めることができる。機能の低下や少化の進行を予め定 めた基準以上に維持するために時間基準保全または状態基準保全の 方策をとることがある。

時間基準保全方策は、洗浄・清揭、調整、補強・補修については 定期保全となり、取り換え修理（単純反復修理）では定期保全のほ かに経時保全が考えられる。

状態基準保全方策をとる場合の保全モードは、保全処置種別の前 に「予防的」と付けて、予防的取り換え修理などと呼ぶことにする。

機能の低下や、劣化の進行が予め定めた基準以下に至ってしまっ た時に行う保全は事後保全であり、各保全処置璉別の前に「事後」 を付けて保全モード名とする。

部品を対象とした保全の場合、総合的保全作業は「オーバーホー ル」であり、他の保全処置は個別保全作業である。分解を伴う点検 により、総合的な保全処置を行う保全をオーバーホールという。応 急的にオーバーホールを行うことは無く、予防保全として行うオー バーホールは、定期オーバーホールあるいは予防的オーバーホール

186
表 7 部品レベルの保全モード

\begin{tabular}{|c|c|}
\hline \multicolumn{2}{|l|}{$\begin{array}{l}\text { ○時間基準保全 } \\
\text { ○緊急保全 }\end{array}$} \\
\hline \multicolumn{2}{|c|}{ 計画的に行う保全の保全モード } \\
\hline \multicolumn{2}{|c|}{ 洔間基準保全方策の場合 } \\
\hline ○定期部品取り替え & ○定期洗浄・清掃 \\
\hline ○経時部品取り替え & ○定期調整 \\
\hline ○定期オーバーホール & ○定期補強・補悠 \\
\hline \multicolumn{2}{|l|}{ 状態基準保全方策の場合 } \\
\hline ○予防的部品取り替え & ○事後部品取り替え \\
\hline ○予防的洗浄・清掃 & ○事後洗浄・清掃 \\
\hline ○予防的調整 & ○事後調整 \\
\hline ○予防的補強・補修 & ○事後補強・補修 \\
\hline ○予防的オーバーホール & ○事後オーバーホール \\
\hline 改良保全の保全モード & \\
\hline
\end{tabular}

表 8 機器、システムレベルの保全モード

\begin{tabular}{|c|c|}
\hline \multicolumn{2}{|l|}{ 機器等の取り替え } \\
\hline 応急的に行う場合の保全モード & ○事後機器等取り替え \\
\hline \multicolumn{2}{|l|}{ 計画的に行う場合の保全モード } \\
\hline 時間基準保全方策の場合 & ○経時機器等取り替え \\
\hline 状態基準保全方策の場合 & ○予防的機器等取り替え \\
\hline 改良取り替えの保全モード & ○改良機器等取り替え \\
\hline \multicolumn{2}{|l|}{ システム更新 } \\
\hline $\begin{array}{l}\text { ○サブシステム更新 } \\
\text { ○システム更新 }\end{array}$ & \\
\hline
\end{tabular}

である。劣化が規定值以上に進んでから、あるいは故障メカニズム が容易に解明できなくてやむを得ず事後保全として機能回復のため に行うオーバーホールは事後オーバーホールとする。オーバーホー ルは本来予防的に行うものであるから、事後オーバーホールは保全 方策としては有り得ず、このモードは保全記録で保全結果を記述す る場合にのみ用いられる。

保全処置の内、改良取り替えは別に分類する必要がある。部品レ ベルでも、高性能の部品に取り換えることにより部位の性能を向上 させ得ることがある。このような目的で行う保全モードを「改良取 り換え」とする。改良取り換えには予防保全、事後保全の区別は当 てはまらない。

(2) 機器、システムレベルの保全モード

機器、システムレベルの保全モードを表 8 に示す。

a . 機器レベルの保全モード

機器等の取り換えも応急的に行うことが有り得る。この場合は事 後機器取り替えとなる。機器等の取り換えを時間基準保全として行 うことは稀であるが、経時保全として取り換えを行う場合は有り得 ると考えられる。一般には状態基準保全として行われる。機器等の 改良取り換えは計画的に行われ、予防保全、事後保全の区分は適用 されない。

b . システムレベルの保全モード

システム更新は、総合的保全として計画的に行われ、予防保全、 事後保全の区分は適用されない。保全形態としてはシステムの一部 (サブシステム) の更新とシステム全体の更新とに分類するにとど める。システム更新の詳細は調査診断曺や設計図青により別途記録 されるからである。 


\section{3 保全頊用支出の判彞根提の記述}

管理の立場からの費用支出判断についての記録を残すこととする。 支出判断は基本的に費用対勃果の評価による。

個々の保全処置の費用が大きくない部品レベルの保全については、 設備の機能性能の基㳯值以上の発揮を前提として、酎用期間におけ る保全貫用の最小化をはかるように保全スケジュール、または保全 実施基準を方針とする。眷用対効果の評価はこれらの方針に折り込 まれる。すなわち、予知保全においては点検スケジュール（点検周 期）、時間基準保全ては保全周期、計画的に劣化の回復をはかるた めの保全の中長期スケジュールや保全実施の劣化程度の规定値など が費用支出判断の根拠となる。稀に部品の改良取り替えがある。こ えは改良の程度とそのための䩀用とが評価されて判断根抱となる。

機器等の取り替えや、システムの更新については、保全責用が大 きいので個別の評価之なる。機器等の取り替えについては建物の長 い酎用期間の中で取り替えが不可欠であるから、取り替え費用の支 出自体の是非は問題にならないが、投資管理上は実施時期あるいは 取り替え基準の最適化が必要となる。ただし、改良保全の場合、改 良の程度とそのための費用增分の評価が管理対象となる。システム 更新は、計面・設計内容か管理対象亡なる。現有システムの機能・ 性能への僬復をはかるのみにとどめるか、改良をはかるか、改良す るとすればどの程度とするかが投瓷管理の対象となる。

表 9 に保全費用支出についての判断根拠の分類を示す。

表 9 保全費用支出についての判断根拋の分類

\begin{tabular}{|c|c|c|}
\hline \multirow{4}{*}{$\begin{array}{l}\text { 部品レベル } \\
\text { の保全 }\end{array}$} & 予知保全 & 点検周期の規定による \\
\hline & 時間基乷保全 & 保全周期の規定による \\
\hline & $\begin{array}{l}\text { 計画的に行う } \\
\text { 保全 }\end{array}$ & $\begin{array}{l}\text { 中長期欢ジ 1ーMによる } \\
\text { 劣化規定值による }\end{array}$ \\
\hline & 改良取り替え & $\begin{array}{l}\text { 改良のための費用增分対改良程度 } \\
\text { の評価による(個別計画) }\end{array}$ \\
\hline \multirow[t]{2}{*}{$\begin{array}{l}\text { 機器レベル } \\
\text { の保全 }\end{array}$} & $\begin{array}{l}\text { 単純反復取り } \\
\text { 替え }\end{array}$ & $\begin{array}{l}\text { 実施時期の最適化による } \\
\text { 機器等の取り替え基準による }\end{array}$ \\
\hline & 改良取り替え & $\begin{array}{l}\text { 改良のための費用增分対改良程度 } \\
\text { の評による(個別計画) }\end{array}$ \\
\hline \multirow[t]{2}{*}{$\begin{array}{l}\text { システム更 } \\
\text { 新 }\end{array}$} & $\begin{array}{l}\text { 物理的劣化の } \\
\text { 回復 }\end{array}$ & 䛯査診断結果による(個別計画） \\
\hline & $\begin{array}{l}\text { 社会的劣化の } \\
\text { 回復 }\end{array}$ & $\begin{array}{l}\text { 社会的劣化の回復のための費用対 } \\
\text { その効果の評伍による(個別計画) }\end{array}$ \\
\hline
\end{tabular}

\section{4 保全記録にお打る記迷力法}

個々の不具合に対する保全は、個々の不具合について、その発生 時期、不効用の内容と程度、不具合のモードとメカニズム、および 不具合の予測情報から特徵つける「不具合の分類」と、保全の一般 化した方法論の観点から分類した「保全モードの分類」、および 「費用支出判断根垉の分類」に基ついて簡潔な記述で記録すること ができ、今後の蓄樍とその分析によって不具合と保全モ一ドとを網 羅的に把握することが可能となると考えられる。以上の保全記録内 容の位置づけを図1に示す。以下にこれまでに述へたような考え方 による保全記録での記述方法をいくつか例示する。

表 10 および表11に物理的少化による不具合とその保全の記録記述 例を示す。表10は二つの機器等の間に故障の伝播があった場合の例 であり、表11は部品レベルの二つの条件が重なったことによる不具 合の列である。このような不具合については兆候がある場合には予

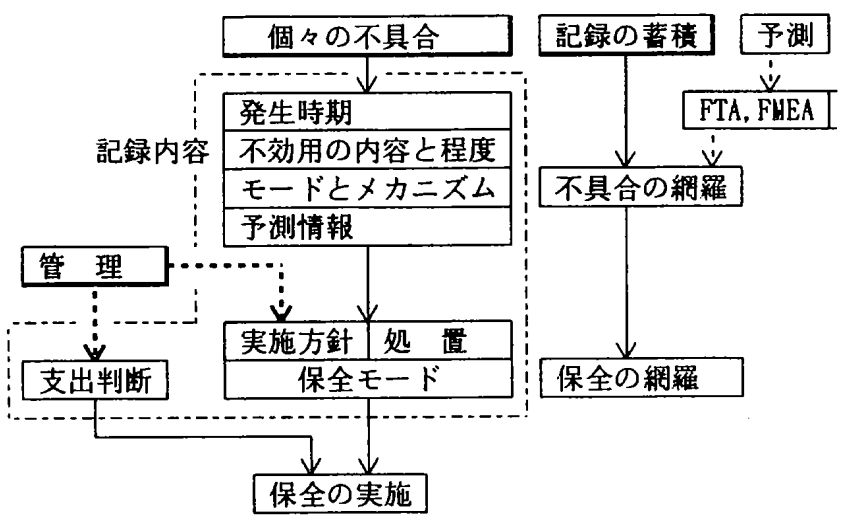

図 1 保全記録の内容の位置づけ

知保全を行うことが可能となる。

表12に性能向上の部品取り替えを行った場合の記述例を示す。最 新技術についての情報によってはじめて不具合と認知される。

染調設備の機器等の陳腐化が重なり、あるいはシステムが全体的 に陳腐化が進み、システム構成の設計を改良する必要がある場合、 採ろべき保全モードは「システム更新」である。システム更新の内 容は保全技術というより設計技術に属するものであるが、その更新 システムの設計に指針を与えるために現有システムの陳腐化の内容 を「故障」の場合と同じように「不効用の内容と程度」、「不具合 メカニズム」、「不具合モード」等によって説明することは保全の 任務である。この例を表13に示す。これも保全記録に含まれるべき ものである。システム更新の実施の判断は、システムを構成する機 器等の物理的劣化状況も反映される。物理的劣化による不具合が改 修工事の実施決定に促進の側の影製を与えるとともに、これらの不 具合への対処についても、保留としたり、取り替えるべところを 一時的延命のための修理にするといった影蔽を受けることになる。

表10 応急処置を要する物理的劣化による不具合(故障の伝搬) とその保全の記録記述例

\begin{tabular}{|c|c|c|c|c|}
\hline \multirow{5}{*}{$\begin{array}{l}\text { 不効用の } \\
\text { 内容と程度 }\end{array}$} & \multicolumn{2}{|c|}{ 不効用発生時期 } & \multicolumn{2}{|c|}{ 既に発生 } \\
\hline & \multicolumn{2}{|c|}{ 不効用の内容 } & \multicolumn{2}{|l|}{ 块適性 } \\
\hline & \multirow{3}{*}{\multicolumn{2}{|c|}{ 不効用の程度 }} & \\
\hline & & & \multicolumn{2}{|c|}{ 損失 評価せず } \\
\hline & & & \multicolumn{2}{|c|}{ 対処費用 評価せず } \\
\hline & \multicolumn{4}{|c|}{ ストレーナ部 } \\
\hline \multirow{3}{*}{$\begin{array}{l}\text { 冷却水配管 } \\
\text { 系 }\end{array}$} & $x 力=\pi^{*} 厶$ & \multicolumn{2}{|c|}{ 固形物付着 } & 欢一付着 \\
\hline & $\begin{array}{l}\text { Z-ド：障害 } \\
\text { Ł-ド }\end{array}$ & \multicolumn{2}{|c|}{$\begin{array}{l}\text { 機能低下 } \\
\text { 流れの異常 }\end{array}$} & $\begin{array}{l}\text { 流量低下 } \\
\text { 忆ーナ部詰まり }\end{array}$ \\
\hline & 予測情報 & \multicolumn{2}{|c|}{ 電流値異常 } & ポソプ 盤アンメータ \\
\hline & \multicolumn{4}{|l|}{ 凝縮器 } \\
\hline \multirow{3}{*}{$\begin{array}{l}\text { 水椧 } n^{0}>\text { - } \\
\text { ジ 空調機 }^{2}\end{array}$} & 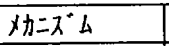 & \multicolumn{2}{|c|}{ 故障の伝搬 } & 冷却水配管系より \\
\hline & $\begin{array}{l}\text { モード : 障害 } \\
\text { モ-ド }\end{array}$ & \multicolumn{2}{|c|}{$\begin{array}{l}\text { 機能停止 } \\
\text { 相変化阻書 }\end{array}$} & $\begin{array}{l}\text { 高圧力フト作動で停止 } \\
\text { 冷媒凝縮不良 }\end{array}$ \\
\hline & 予測情報 & \multicolumn{2}{|c|}{ 圧力異常 } & 高压侧冷媒圧力上昇 \\
\hline 保全 $\mathrm{E}-ト^{\circ}$ & \multicolumn{3}{|l|}{ 緊急保全 } & 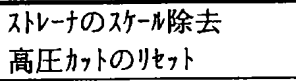 \\
\hline 支出判断 & \multicolumn{4}{|l|}{ 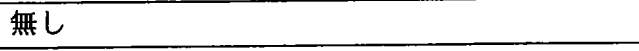 } \\
\hline
\end{tabular}


表11 応急処置を要しない物理的劣化による不具合とその保全 の記録記述例

\begin{tabular}{|c|c|c|c|c|}
\hline \multirow{5}{*}{$\begin{array}{l}\text { 不効用の } \\
\text { 内容と程度 }\end{array}$} & \multicolumn{2}{|c|}{ 不効用発生時期 } & \multicolumn{2}{|c|}{ 既に発生 (コ价)・未然(ドレンパン) } \\
\hline & \multicolumn{2}{|c|}{ 不効用の内容 } & \multicolumn{2}{|c|}{ 快適性 } \\
\hline & \multirow{3}{*}{\multicolumn{2}{|c|}{ 不効用の程度 }} & 発生日時 ○月О日00:00 & 回復日時 ○月О日OO：00 \\
\hline & & & \multicolumn{2}{|c|}{ 損失 $\quad$ 評価せず } \\
\hline & & & \multicolumn{2}{|c|}{ 対処費用 $\mathrm{OOM}$} \\
\hline & \multicolumn{4}{|l|}{$\mathrm{AHU}$} \\
\hline \multirow{3}{*}{$\begin{array}{l}\text { 冷温水コ傆 } \\
\text { のチューブ }\end{array}$} & 加スズム & \multicolumn{2}{|c|}{$\begin{array}{l}\text { 固形物付着 } \\
\text { 機能低下 }\end{array}$} & 欢-n付着 \\
\hline & $\begin{array}{l}\text { モード：障害 } \\
\text { モード }\end{array}$ & \multicolumn{2}{|c|}{$\begin{array}{l}\text { 機能低下 } \\
\text { 熱伝達阻害 }\end{array}$} & $\begin{array}{l}\text { 冷房能力低下規定超過 } \\
\text { チューブ内部の污れ }\end{array}$ \\
\hline & 予測情報 & \multicolumn{2}{|c|}{ 室内環境 } & 室温不良 \\
\hline \multirow[t]{3}{*}{ ドレパン } & 加ニズム & \multicolumn{2}{|c|}{ 腐食 } & 侵食 \\
\hline & $\begin{array}{l}\text { モード: 障害 } \\
€-ト^{\circ}\end{array}$ & \multicolumn{2}{|c|}{$\begin{array}{l}\text { 機能低下 } \\
\text { 流れの阻害 }\end{array}$} & $\begin{array}{l}\text { 現状で障害無し } \\
\text { 水漏れが予見される }\end{array}$ \\
\hline & 予測情報 & \multicolumn{2}{|c|}{ 見えがかり } & 点検時に発見 \\
\hline \multirow[t]{2}{*}{ 保全 } & \multicolumn{3}{|c|}{ 冷温水J伍：事後洗浄 } & $f_{1}-フ^{*}$ の洗浄 \\
\hline & \multirow{2}{*}{\multicolumn{3}{|c|}{$\begin{array}{l}\text { ドレンク゚ン：予防的補修 } \\
\text { 冷温水コ价：無し }\end{array}$}} & 錆落とし、叙装 \\
\hline \multirow[t]{2}{*}{ 支出判断 } & & & \multirow{2}{*}{\multicolumn{2}{|c|}{ 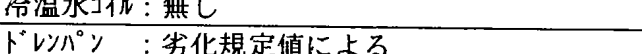 }} \\
\hline & ドレハパン : & & & \\
\hline
\end{tabular}

表12 性能向上の部品取り替えの記述例

\begin{tabular}{|c|c|c|c|}
\hline \multirow{4}{*}{$\begin{array}{l}\text { 不効用の } \\
\text { 内容と程度 }\end{array}$} & \multicolumn{2}{|c|}{ 不効用発生時期 } & 既に発生 \\
\hline & \multicolumn{2}{|c|}{ 不効用の内容 } & 経済性、社会性 \\
\hline & \multirow{2}{*}{\multicolumn{2}{|c|}{ 不効用の程度 }} & 損失 000 円 \\
\hline & & & 対処費用 000 円 \\
\hline 部品 & \multicolumn{3}{|l|}{ 圧縮機 } \\
\hline \multirow{3}{*}{ 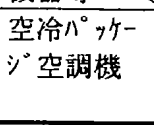 } & 㭊ニ゙ム & \multicolumn{2}{|c|}{ 陳腐化（技術進歩による） } \\
\hline & $z-r^{*}$ & \multicolumn{2}{|c|}{ 省エ祃ギー性不良 } \\
\hline & 予測情報 & \multicolumn{2}{|r|}{ 最新技術との格差 } \\
\hline 保全 $t-r^{*}$ & \multicolumn{2}{|c|}{ 改良取り替え } & \begin{tabular}{|l|l} 
& $\begin{array}{l}\text { 省工神 } \\
\text { り替え } \text { 型圧縮㙨に取 }\end{array}$ \\
\end{tabular} \\
\hline 支出判断 & \multicolumn{3}{|c|}{ 改良のための費用增分対改良程度の評価による } \\
\hline
\end{tabular}

表13 システム全体の不具合とその保全の記述例

\begin{tabular}{|c|c|c|c|c|}
\hline \multirow{4}{*}{$\begin{array}{l}\text { 不効用の } \\
\text { 内容亡程度 }\end{array}$} & \multicolumn{2}{|c|}{ 不効用発生時期 } & \multicolumn{2}{|c|}{ 既に発生 (冷却塔)、他は未然 } \\
\hline & \multicolumn{2}{|c|}{ 不効用の内容 } & \multicolumn{2}{|c|}{ 経済性、環境性 } \\
\hline & \multirow{2}{*}{\multicolumn{2}{|c|}{ 不効用の程度 }} & \multicolumn{2}{|c|}{ 損失 } \\
\hline & & & \multicolumn{2}{|c|}{ 対処費用 } \\
\hline & \multicolumn{4}{|c|}{ 空調システム：各階水冷パフケージ 空調機単一ダクト方式 } \\
\hline 機器等 & 冷却塔 & \multicolumn{3}{|c|}{ 沅么全体 } \\
\hline 妨ニズム & 環境不久 & \multicolumn{2}{|c|}{ 要求水準上昇 } & 環境·動作ストレス \\
\hline E-ド：障害 & 機能低下 & \multirow{2}{*}{\multicolumn{2}{|c|}{ 陳腐化 }} & 機能低下他 \\
\hline E-ド & 全体的劣化 & & & シ人徨全体的劣化 \\
\hline 予测情報 & 見えがかり & \multicolumn{2}{|c|}{$\begin{array}{l}\text { クレームの增加 } \\
\text { 最新設備性能टの } \\
\text { 格差 }\end{array}$} & 全体的劣化進行 \\
\hline 保全 $ヒ-r^{*}$ & $\begin{array}{l}\text { 予防的機器 } \\
\text { 取り替え } \\
\text { (当面保留) }\end{array}$ & \multicolumn{3}{|c|}{ シスデ全体更新の計画 } \\
\hline 支出判断 & \multicolumn{4}{|c|}{ 費用対効果の評価による } \\
\hline
\end{tabular}

\section{まとめ}

灴調設備の個々の保全を効率的にかつ簡潔に記録する方法の開発 に向けた研究について報告した。この記録方法開発の意図は、蓄積 された記録データの分析によって、保全方針の高品質化をはかり、
また、設計段階にフィードバックする。更に、最終的な目的として、 空調設備の保全実態を体系的に整理して全体像を把握することを想 定している。

このような開発意図のためには、保全を動機付ける不具合を明確 に記録することが重要である。複雑な不具合を効率的にかつ簡潔に 記述するために、不具合の分類観点を、「不具合の発生時期」、 「不効用の内容と程度」、「不具合のモードとメカニズム」および 「不具合の予測情報」とし、それぞれの分類観点の選択肢を網羅的 に提示した。また、記録の蓄積による不具合の網羅が、F T A P F ME Aの手法によるよりも保全寒態を体系的に整理して全体像を把 握するという目的には現実的なアプローチであることを論じた。

不具合に対する保全については、「保全実施方針」と「保全処置 の分類」を行い、その組み合わせから「保全モード」の分類を保全 記録の選択肢として網羅的に提示した。また、保全への「郿用支出 判断」に関する記録内容を示した。

最後に、保全記録において、不具合と保全について統合して記述 する方法を事例によって示した。

注 記

1. J IS生産管理用語（設㣁管理）28143-1986では、「設備保全」を、「設備 本来の機能を発揮し、運転、使用可能な状態に維持するとともに、故障、久 陥などを回復するための処置及び活動」と定義している。

2. JIS生産管理用語（設䚛管理）Z8143 1986では、「設偖管理」を、「設诺 の㖕画、調達から、運転、維持を経て廃印に至るまで、設暴を効果的に活用 するための管理」と定義している。

3. JIS生産管理用語（基本）28141-1983では「管理」を、「決定された経営 意志に従って、経営計画の運営・維持を目的とした執行の計画・統制・調整 の活動」と定莪している。

\section{文 献}

1）日本規格协会：J I S 用語辞典 基本・一般編第 3版、pp. 136-154, 1989 年9月. 日本規格協会

2) 大島榮次、師岡孝次：設備管理工学人門、日本規格協会、1992年3月

3）高草木 明：空調設倫の予防保全に関する解析的研究、日本建築学会㖕 画系論文報告集［搹文］、N0.430.pp. 45-53.1991年12月

4) 高草木 明：状態基準予防保全の信頼性向上効果之経済性の分析 空調 設備の予防保全に関する解析的研究その 2、日本建策学会計画系諭文報 告集 [論文]、N0.441.pp. 43-52.1992年11月

5 ）高草木 明：空調設借の物理的劣化の回復のための保全貫用に関する腤 查研究、日本建築学会㖕画系論文集、N0.459,pp. 27-36.1994年5月

6 ) 高草木 明：空調設備の更新に関する理論的研究、日本建策学会計画采 論文報告集［論文］、N0.435, pp. 23-31，1992年5月

7) 高草木 朋：貨貨事務所建物の集中的改佟の計画における社会的劣化の 回復への投資評価に関する研究、日本建策学会計画系論文集、N0.505 pp. 159-166. 1998年3月

8 ) 高草木 明：㞬調設備の信頼度・保企度調查研究、日本建策学会計画系 論文報告集［論文］、N0.436, pp. 1-9.1992年6月

9 ）塩見 弘:故障物理入門、日科技連出版社、1970年2月

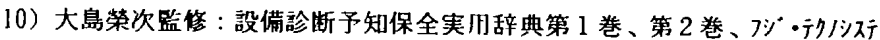
4, 1988年

11）塩見弘、島風漳、石川敬幸：日科技速信頼性工学沙-ス゚第7巻 F M E A , F T A 活用、日科技連出版社、1998年3月

12）高草木 明：空調設满の保全手法の体系的整理方法に関する研究、環境 の管理、第10号、pp. 41-50、日本䍗境管理学会、1993年8月

[1999年10月14日原稿受理２000年 2 月 2 日採用決定］ 